\title{
Penatalaksanaan stomatitis aftosa rekuren mayor dengan infeksi sekunder Management of major recurrent aphtous stomatitis accompanied by secondary infection
}

\author{
${ }^{1}$ Nurdiana, ${ }^{2}$ M. Jusri \\ ${ }^{1}$ Peserta Program Pendidikan Dokter Gigi Spesialis Oral Medicine \\ ${ }^{2}$ Bagian Oral Medicine \\ Fakultas Kedokteran Gigi Universitas Airlangga \\ Surabaya, Indonesia
}

\begin{abstract}
Recurrent aphthous stomatitis (RAS) is an ulcerative condition that affects the oral mucosa without evidence of underlying disorder. It's characterized by the appearance of recurring round, shallow ulcerations surrounded by inflammation that mainly involves the nonkeratinized mucosa. The classification of SAR are minor, major, and herpetiform types. Although rare, secondary infection may occur. Treatment is directed to avoid local traumatic precipitants, lessen the pain and duration of ulceration by suppressing the local immune response, and prevent secondary infection. The objective of this paper is to discuss the treatment of RAS with secondary infection, a case of 24-year-old man with multiple large ulcers that did not heal for almost 4 weeks. The ulcers were diagnosed as major RAS with secondary infection, and treated with metronidazole and ciprofloxacin, healed in 2 weeks with scars. Although secondary infection will delay healing, but with proper treatment, major RAS has good prognosis.

Key words: recurrent aphthous stomatitis, major RAS, secondary infection, metronidazole, ciprofloxacin
\end{abstract}

\section{ABSTRAK}

Stomatitis aftosa rekuren (SAR) adalah kondisi ulseratif pada mukosa oral tanpa adanya kelainan lain. Karakteristik SAR adalah ulserasi bulat, dangkal, rekuren yang dikelilingi oleh inflamasi dan terutama melibatkan mukosa nonkeratinisasi. Klasifikasi SAR adalah minor, mayor, dan herpetiformis. Infeksi sekunder jarang terjadi. Perawatan ditujukan untuk menghindari trauma lokal, mengurangi rasa nyeri dan durasi ulserasi dengan menekan respon imun lokal, dan mencegah infeksi sekunder. Tujuan penulisan artikel ini adalah mendiskusikan perawatan seorang pria 24 tahun dengan ulser yang besar, jamak dan tidak sembuh selama 4 minggu. Ulser didiagnosis SAR mayor dengan infeksi sekunder, sembuh dalam 2 minggu, meninggalkan sikatrik setelah dirawat dengan metronidazol dan siprofloksasin. Meskipun infeksi memperlambat penyembuhan, tetapi dengan perawatan yang tepat, SAR mayor memiliki prognosis yang baik.

Kata kunci: stomatitis aftosa rekuren, SAR mayor, infeksi sekunder, metronidazol, siprofloksasin

Koresponden: Nurdiana, Peserta Pendidikan Dokter Gigi Spesialis Oral Medicine, Fakultas Kedokteran Gigi Universitas Airlangga. J1. Mayjen Prof. Dr. Moestopo No. 47, Surabaya 60132, Indonesia

\section{PENDAHULUAN}

Stomatitis aftosa rekuren (SAR) merupakan kondisi ulseratif pada rongga mulut yang paling umum terjadi. ${ }^{1}$ SAR ditandai oleh ulser rekuren, tunggal atau jamak, nyeri, berbentuk bulat atau oval, ditutupi oleh pseudomembran putih sampai kuning atau abu-abu, berbatas jelas dan memiliki eritema halo. ${ }^{2-5}$

Secara klinis SAR dibedakan atas minor, mayor, dan herpetiformis. ${ }^{2-3,6-7}$ SAR mayor (periadenitis mucosa necrotica recurrent atau Sutton's disease) jarang terjadi (sekitar 10\%), tapi paling parah. ${ }^{2,4,68-9}$ Ulser SAR mayor berdiameter lebih dari $1 \mathrm{~cm},{ }^{2,4,8-10}$ lebih dalam daripada SAR minor dan sering memiliki batas eritema ireguler yang meninggi. ${ }^{11}$ SAR mayor sering terjadi pada mukosa labial, palatum lunak, dan orofaring. ${ }^{49-10}$ Ulser sembuh dalam 6 minggu dan sering menyebabkan sikatrik. ${ }^{7,11-12}$ SAR mayor biasanya mulai terjadi setelah pubertas dan menetap selama 20 tahun atau lebih. ${ }^{2,4,911}$ Kesehatan sistemik dapat terganggu karena kesulitan atau rasa sakit saat makan dan stres psikologis. ${ }^{8}$

Insidens SAR terjadi pada $2-66 \%$ dari populasi di dunia, ${ }^{12}$ biasanya mulai pada masa anak-anak ( $80 \%$ pasien berusia kurang dari 30 tahun) dan berkurang frekuensi dan keparahannya sejalan dengan usia. ${ }^{7,9,11}$ Penelitian cross-sectional menyatakan SAR lebih umum terjadi pada perempuan, individu berusia di bawah 40 tahun, ras Kaukasia, bukan perokok, dan individu dari status sosioekonomi tinggi. ${ }^{5,7}$

Meskipun tidak ada penyebab utama atau spesifiknya, ${ }^{8}$ SAR dapat dikaitkan dengan trauma lokal, stres, alergi makanan, perubahan hormon, defisiensi nutrisi atau vitamin, predisposisi genetik, disregulasi imun, infeksi lokal, kelainan sistemik, dan paparan bahan kimia. ${ }^{1,11}$ 
Tidak ada perawatan kuratif untuk SAR. Perawatan ditujukan untuk menghindari trauma lokal, mengurangi rasa sakit atau rasa tidak nyaman dan memperpendek durasi ulserasi dengan menekan respon imun lokal, dan mencegah infeksi sekunder. ${ }^{2,4}$ Meskipun tidak ada perawatan definitif untuk SAR, penggunaan antiinflamasi imunosupresif topikal, terutama kortikosteroid, analgesik, atau kortikosteroid sistemik adalah cara perawatan utama. ${ }^{7}$

Pada kasus ini, pasien mengalami SAR mayor selama 4 minggu. Secara klinis dijumpai ulser multipel yang merupakan SAR mayor dan minor. Sebelumnya pasien pernah mengalami lesi yang sama kira-kira 11 bulan yang lalu.

Lewat tulisan ini akan didiskusikan mengenai tatalaksana SAR mayor yang disertai dengan infeksi sekunder.

\section{KASUS}

Pada tanggal 13 Oktober 2008, pasien pria berusia 23 tahun datang ke Klinik Penyakit Mulut Fakultas Kedokteran Gigi Universitas Airlangga Surabaya. Dari anamnesis diketahui pasien mengalami sariawan di bibir kanan bawah sejak 4 minggu yang lalu. Sariawan terjadi tiba-tiba tanpa penyebab. Awalnya sariawan kecil, kemudian dengan cepat berubah besar dan sakit sehingga mengganggu ketika makan dan berbicara, tetapi tidak diobati sebelumnya. Pasien mengalami sariawan setidaknya satu bulan sekali, dan kondisi seperti ini pernah dialami kira-kira 11 bulan yang lalu. Pada akhir perawatan sebelumnya, pasien diinstruksikan untuk mencabut sisa akar gigi molar pertama kanan atas dan bawah serta membersihkan kalkulus, tetapi pasien tidak melakukan instruksi tersebut.

Pemeriksaan klinis menunjukkan keadaan umum pasien adalah baik. Pada riwayat medis dan riwayat keluarga diketahui tidak ada kelainan. Pemeriksaan ekstra oral memperlihatkan sedikit pembengkakan pada pipi kanan, dan limfadenitis kronis pada kelenjar submandibular kanan.

Pada mukosa labial kanan bawah tampak bentuk ulser tidak beraturan, ukuran $\pm 10 \mathrm{~mm}$, batas jelas dan meninggi, sedikit eritema, ditutupi pseudomembran putih (gambar 1A), dan oval, ukuran $8 \times 5 \mathrm{~mm}$, batas jelas dan meninggi, sedikit eritema, ditutupi pseudomembran putih (gambar 1B). Pada mukosa bukal kanan tampak ulser bulat, diameter $\pm 15 \mathrm{~mm}$, batas jelas dan meninggi, terdapat eritema, ditutupi pseudomembran putih (gambar 1C). Selain ulser, terdapat sisa akar molar pertama kanan atas dan bawah, dan kalkulus.

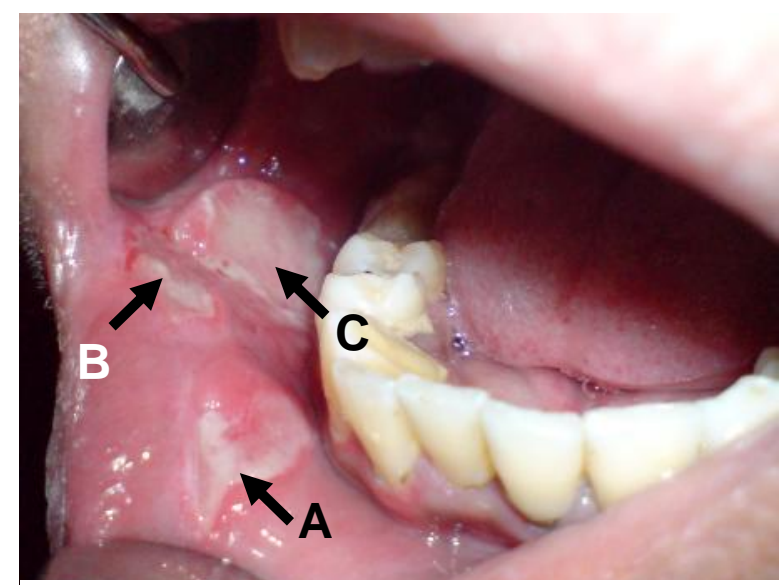

Gambar 1. Tampakan intra oral pada kunjungan pertama, ulser multipel pada mukosa labial kanan bawah dan mukosa bukal kanan

\section{TATALAKSANA KASUS}

Berdasarkan anamnesis, pemeriksaan klinis, dan riwayat penyakit, diagnosis klinis kasus ini adalah SAR mayor, dengan diagnosis banding ulkus traumatikus dan karsinoma sel skuamosa. Berdasarkan riwayat penyakit sebelumnya, dilakukan hapusan untuk pemeriksaan bakteri dan diinstruksikan melakukan pemeriksaan darah lengkap, SGOT, dan SGPT. Pasien dirawat dengan triamcinolone acetonide in orabase $0,1 \%$ 3 kali/hari dan obat kumur klorheksidin 3 kali/hari selama 7 hari.

Dua hari kemudian (15 Oktober 2008), didapat hasil pemeriksaan bakteri, yang menunjukkan adanya kuman coccus berderet Gram positif. Hasil pemeriksaan darah tidak memperlihatkan adanya kelainan. Pasien diberi terapi tambahan, yaitu metronidazol $500 \mathrm{mg} 3$ kali/hari dan siprofloksasin $500 \mathrm{mg} 2$ kali/hari selama 5 hari.

Lima hari kemudian (20 Oktober 2008), berdasarkan anamnesis diketahui rasa sakit dan pembengkakan sudah berkurang. Sisa akar gigi molar pertama kanan atas telah diekstraksi. Pada pemeriksaan ekstra oral tidak ada kelainan. Pemeriksaan intra oral pada mukosa labial kanan bawah memperlihatkan ulser menjadi lebih kecil, ukuran $\pm 7 \mathrm{~mm}$, batas tidak jelas dan tanpa eritema (Gambar 2A), sedangkan ulser kedua sudah sembuh dan terbentuk sikatrik (Gambar 2B). Ulser pada mukosa bukal kanan menjadi lebih kecil, diameter $\pm 10 \mathrm{~mm}$ (Gambar 2C). Pasien dirawat dengan triamcinolone acetonide in orabase $0,1 \% 3 \mathrm{kali} / \mathrm{hari}$ dan obat kumur klorheksidin 3 kali/hari selama 7 hari, serta metronidazol $500 \mathrm{mg} 3 \mathrm{kali} / \mathrm{hari}$ dan siprofloksasin $500 \mathrm{mg}, 2 \mathrm{kali} /$ hari selama 3 hari. 


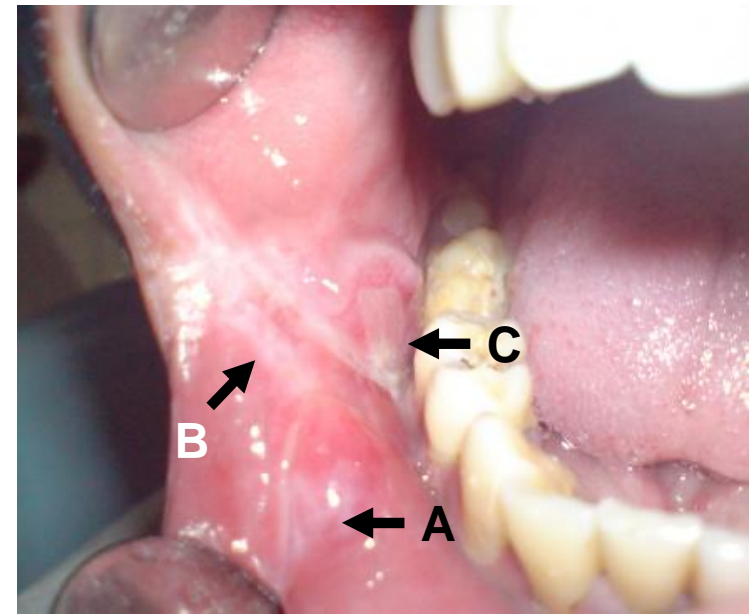

Gambar 2.Tampakan intra oral kunjungan kedua. ulser pada mukosa labial kanan bawah sudah sembuh dan membentuk sikatrik, ulser mukosa bukal kanan menjadi lebih kecil.

Berdasarkan anamnesis tujuh hari kemudian (27 Oktober 2008) diketahui tidak ada rasa sakit. Sisa akar gigi molar pertama kanan bawah telah diekstraksi dan kalkulus telah dibersihkan. Pemeriksaan intra oral memperlihatkan seluruh ulser sudah sembuh dan terbentuk sikatriks (Gambar 3B), bandingkan dengan keadaan pada saat kunjungan pertama (Gambar 3A). Selanjutnya agar kondisi seperti ini tidak terjadi kembali, pasien diinstruksikan untuk selalu menjaga kebersihan rongga mulutnya.

\section{PEMBAHASAN}

Diagnosis SAR ditentukan terutama berdasarkan riwayat ulser rekuren sejak masa kanak-kanak, meskipun sejumlah kecil kasus pertama kali terjadi pada usia yang lebih tua dan adanya ulser bulat atau oval yang khas pada pemeriksaan klinis. ${ }^{5}$ Dari riwayat penyakit pasien ini diketahui bahwa ulser seperti ini sudah pernah terjadi sebelumnya dan pasien sering mengalami sariawan setidaknya satu bulan sekali. Pemeriksaan intra oral memperlihatkan beberapa ulser dengan gambaran klinis yang berbeda-beda yaitu ulser dengan karakteristik SAR pada mukosa labial kanan bawah dan ulser tanpa eritema halo yang menunjukkan suatu lesi kronis pada mukosa bukal kanan. Karakteristik SAR mayor adalah ulser oval berukuran lebih dari $1 \mathrm{~cm}$. SAR mayor merupakan bentuk yang relatif parah karena beberapa ulser dapat terjadi secara bersamaan. Ulser mayor lebih besar dan lebih dalam dari pada ulser minor, memiliki batas tidak teratur, dan beberapa ulser dapat bersatu. ${ }^{12}$ Ulser dapat terjadi selama lebih dari 2 minggu dan sering menyebabkan sikatriks ketika sembuh. ${ }^{6}$ SAR mayor mulai terjadi setelah pubertas dan dapat menetap selamanya, meskipun setelah masa dewasa akhir episode SAR mayor menjadi sangat jarang. ${ }^{12}$ SAR terjadi pada area mukosa nonkeratinisasi dan tidak cekat, terutama mukosa bukal, mukosa labial, dasar mulut, ventral lidah, dan palatum lunak. ${ }^{11}$

Berdasarkan riwayat rekurensi dan gambaran klinis, yaitu ulser multipel dengan karakteristik SAR, maka diagnosis klinis kasus ini adalah SAR mayor, dengan diagnosis banding ulser traumatikus dan karsinoma sel skuamosa.

Adanya riwayat ulser rekuren dan tanda infeksi kronis, maka kemungkinan karsinoma sel skuamosa dapat dikesampingkan. Ulkus traumatikus juga dipertimbangkan sebagai diagnosis banding pada kasus ini. Ulkus traumatikus pada mukosa oral memperlihatkan tanda dan simptom inflamasi akut, yaitu rasa sakit, kemerahan dan pembengkakan. Ulser ditutupi oleh eksudat fibrin putih kekuningan dan dikelilingi oleh eritema halo. Sebagian besar ulkus
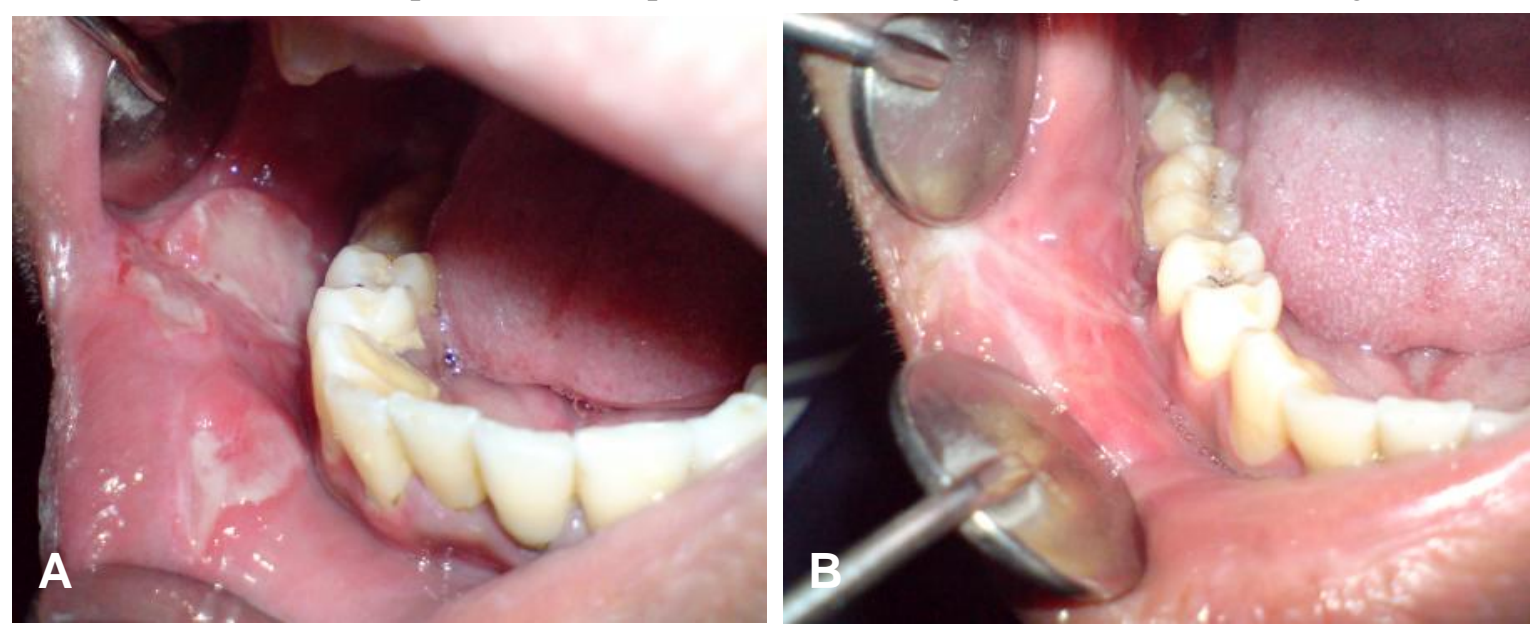

Gambar 3. Perbandingan lesi pada: A. kunjungan pertama, dan B. kunjungan ketiga setelah 14 hari. Seluruh ulser telah sembuh dan membentuk sikatriks. 
traumatikus disebabkan oleh trauma mekanis, dan hubungan antara penyebab dan efek biasanya sangat jelas. ${ }^{13}$ Ulser pada kasus ini hampir menyerupai ulkus traumatikus tetapi tanpa tanda dan simptom inflamasi akut. Disamping itu, berdasarkan anamnesis diketahui bahwa tidak terjadi trauma sebelum timbulnya ulser.

Secara klinis kasus ini merupakan ulser mayor yang disertai dengan tanda infeksi kronis tanpa adanya keterlibatan kelainan atau penyakit lain yang ditunjukkan oleh hasil pemeriksaan darah lengkap yang normal. Ditemukannya kuman coccus berderet Gram positif pada hasil pemeriksaan bakteri, maka diagnosis akhir kasus ini adalah SAR mayor dengan infeksi sekunder.

Kami beranggapan bahwa lesi tidak sembuh selama 4 minggu karena adanya kontaminasi lesi oleh bakteri dari sisa akar gigi molar pertama kanan atas dan bawah, serta kalkulus. Hal ini didukung oleh hasil pemeriksaan bakteri dari hapusan ulser yang menunjukkan adanya kuman coccus berderet Gram positif.

Infeksi odontogenik disebabkan oleh campuran bakteri aerob dan anaerob (70\%). Hal ini memiliki implikasi klinis yang besar, yaitu antibiotik yang bermanfaat untuk infeksi odontogenik harus efektif melawan bakteri aerob dan anaerob. Bakteri aerob yang dijumpai pada infeksi odontogenik terutama coccus Gram positif, kebanyakan adalah Streptococcus tipe viridans. Spesies streptococcus ini merupakan flora oral dan termasuk Streptococcus milleri, S. sanguis, $S$. salivarius, dan S. mutans. Streptococcus oral ini disebut juga Streptococcus $\alpha$ hemolitik dan merupakan $85 \%$ bakteri aerob yang dijumpai pada infeksi odontogenik. ${ }^{14}$

Jumlah bakteri anaerob yang dijumpai pada infeksi odontogenik lebih besar daripada jumlah bakteri aerob. Terdapat dua kelompok utama bakteri anaerob, yaitu coccus Gram positif anaerob dan batang Gram negatif anaerob. Dua kelompok utama coccus Gram positif anaerob adalah Streptococcus anaerob dan Peptostreptococcus. ${ }^{14}$

Terapi SAR ditujukan untuk menekan dan menghilangkan gejala karena tidak adanya bukti yang jelas untuk perawatan SAR. Pada kebanyakan pasien, gejala SAR dapat dihilangkan dengan menggunakan kortikosteroid topikal, obat imunomodulator topikal, atau terapi kombinasi. Meskipun obat ini dapat mengurangi rasa sakit dan inflamasi, tetapi sebagian besar manfaat dan kerja obat ini paling baik untuk SAR minor. ${ }^{10}$
Perawatan kasus ini adalah merawat infeksi sekunder dan mempercepat penyembuhan SAR. Metronidazol dan siprofloksasin diberikan untuk merawat infeksi yang sangat mungkin disebabkan oleh campuran bakteri aerob dan anaerob. Metronidazol aktif melawan sebagian besar bakteri anaerob. Obat ini berdifusi ke dalam bakteri tempat gugus nitro direduksi. Selama proses reduksi ini, terbentuk intermediat yang reaktif secara kimia, yang menghambat sintesis DNA dan/atau merusak DNA sehingga mengganggu fungsi bakteri. ${ }^{15}$ Dosis metronidazol adalah $500 \mathrm{mg}$ per oral setiap 8 jam. $^{14}$ Siprofloksasin mempunyai substituen 6-fluoro yang sangat memperkuat potensi antibakteri melawan bakteri Gram positif dan terutama Gram negatif. ${ }^{15}$ Obat ini mengganggu enzim bakteri yang sangat penting untuk transkripsi DNA. Dosis dewasa untuk siprofloksasin adalah $500-700 \mathrm{mg}$ per oral setiap 12 jam. ${ }^{14}$

Pasien diberi triamcinolone acetonide in orabase $0,1 \% 3 \mathrm{kali} / \mathrm{hari}$ untuk mengurangi rasa sakit dan memperpendek durasi ulserasi dengan menekan respon imun lokal, serta sebagai covering agent untuk mempercepat epitelisasi. Obat kumur klorheksidin diberikan untuk membantu penyembuhan ulser. Meskipun tidak ada bukti bahwa SAR disebabkan oleh infeksi bakteri tetapi terdapat beberapa penelitian yang menunjukkan bahwa beberapa antimikroba topikal (terutama klorheksidin glukonat) dapat memperpendek durasi ulser SAR. ${ }^{2}$

\section{SIMPULAN}

Disimpulkan bahwa SAR mayor pada kasus ini telah terkontaminasi oleh bakteri sehingga terjadi infeksi sekunder. Oleh karena itu perawatan kasus ini ditujukan untuk merawat infeksi sekunder dan mempercepat proses penyembuhan ulser. Melalui perawatan yang tepat yaitu pemberian metronidazol dan siprofloksasin untuk merawat infeksi sekunder dan triamcinolone acetonide in orabase $0,1 \%$ dan obat kumur klorheksidin untuk mempercepat proses penyembuhan ulser, sehingga SAR mayor ini sembuh dalam waktu 2 minggu.

\section{DAFTAR PUSTAKA}

1. Safadi RA. Prevalence of recurrent aphthous ulceration in Jordanian dental patients. Available from: http://www.biomedcentral. com/14726831/9/31. Accessed on 29 Desember 2009.

2. Jurge S, Kuffer R, Scully C, Porter SR. Recurrent aphthous stomatitis. Oral Dis 2006; 12: 1-21. 
3. Gonsalves WC, Chi AC, Neville BW. Oral lesions: Part I. Superficial mucosal lesions. Am Fam Phys 2007; 75: 501-7.

4. Scully C, Porter S. Oral mucosal disease: Recurrent aphthous stomatitis. Br J Oral Maxillofac Surg 2008; 46: 198-206.

5. Scully C. Aphthous ulceration. New Engl J Med 2006; 355 (2): 165-72.

6. Wilhelmsen NSW, Weber R, Monteiro F, Kalil J, Dieb Miziara ID. Correlation between histocompatibility antigens and recurrent aphthous stomatitis in the brazilian population. Braz $\mathbf{J}$ Otorhinolaryngol 2009; 75 (3): 426-31.

7. Gorsky M, Epstein JB, Rabenstein S, Elishoov H, Yarom N. Topical minocycline and tetracycline rinses in treatment of recurrent aphthous stomatitis: a randomized cross-over study. Available from:http://dermatology.

cdlib.org/132/original/tcn/gorsky.html. Accessed on 29 Desember 2009.

8. Sciubba JJ. Oral mucosal disease in the office setting-Part I: aphthous stomatitis and herpes simplex infections. Available from: http://www.agd.org/publications/articles/?ArtID=18 58. Accessed on 4 Januari 2008.
9. Cohen RB. Stomatitis. Available from: http://www.merck.com/mmpe/sec08/ch094/ch094e/ html\#sec08-ch094-ch094c-923ii.htm. Accessed on 30 Desember 2009.

10. Generali J, Cada DJ. Pentoxifylline: Aphthous stomatitis. Hospital Pharmacy 2007; 42 (12): 1117 26.

11. Plewa MC. Aphthous ulcers. Available from: http://emedicine.medscape.com/article909213.htm. Accessed on 29 Desember 2009.

12. Casiglia JM, Mirowski GW. Aphthous Stomatitis. Available from: http://www. emedicine.com/derm/topic 486.htm. Accessed on 8 Januari 2008.

13. Regezi JA, Sciubba JJ, Jordan RCK. Oral pathology. Clinical pathologic correlations. $4^{\text {th }} \mathrm{Ed}$. St. Louis: Saunders; 2003. p. 23-6.

14. Peterson LJ. Principles of surgical and antimicrobial infection management. Antimicrobial pharmacology for maxillofacial infection. In: Topazian RG, Goldberg MH, Hupp JR. Oral and maxillofacial infections. $4^{\text {th }}$ Ed. Philadelphia: WB Saunders Company; 2002. p. 101-3, 121.

15. Neal MJ. At a glance farmakologi medis. Alih bahasa: Juwalita S, Amalia S. Jakarta: Penerbit Erlangga; 2005, h. 80-1. 